DOI: 10.12731/2658-6649-2021-13-3-89-102

UDC 636.084.1

\title{
USE OF THE ORGANOMINERAL FEED ADDITIVES FOR RAISING YOUNG CATTLE IN THE CONDITIONS OF YAKUTIA
}

\section{M.F. Grigorev, A.I. Grigoreva, A.A. Sidorov, A.V. Popova}

The article presents results of studies of the effectiveness of the organomineral feed additives from natural raw materials using in the raising young cattle in the conditions of Yakutia. The research was carried out on cattle, which were divided into three equal groups. The selection of animals was carried out taking into account the method of analogs, where such parameters as age, live weight, clinical indicators were taken into account. In accordance with the research program, cattle from two experimental groups consumed experimental feed additives, while animals from the control group were solely given the basic ration. The inclusion of organomineral feed additives into the ration of gobies made it possible to increase the live weight at the end of rearing by $3.3 \%$ and $5.47 \%$. These changes are best expressed in growth rate over periods. In the experimental groups the growth rate indicators improved in the 9-12-month-old period by $2.42 \%$ and $3.23 \%$, at the 12-15 months of age by $0.57 \%$ and $0.85 \%$, and at $15-18$ months of age by $16.01 \%$ and $24.47 \%$. Thus, the use of organomineral feed additives from natural raw materials in feeding of young cattle in Yakutia it possible to improve the efficiency of their rearing.

Keywords: cattle raising; feed additives; efficiency; growth rate; live weight

For citation. Grigorev M.F., Grigoreva A.I., Sidorov A.A., Popova A.V. Use of the Organomineral Feed Additives for Raising Young Cattle in the Conditions of Yakutia. Siberian Journal of Life Sciences and Agriculture, 2021, vol. 13, no. 3, pp. 89-102. DOI: 10.12731/2658-6649-2021-13-3-89-102

\section{ИСПОЛЬЗОВАНИЕ ОРГАНОМИНЕРАЛЬНЫХ КОРМОВЫХ ДОБАВОК ПРИ ВЫРАЩИВАНИИ МОЛОДНЯКА КРУПНОГО РОГАТОГО СКОТА В УСЛОВИЯХ ЯКУТИИ}

\section{М.Ф. Григорьев, А.И. Григорьева, А.А. Сидоров, А.В. Попова}

В статье представлены результаты исследований эффективности использования органоминеральных кормовых добавок из природного сырья в 
выращивании молодняка крупного рогатого скота в условиях Якутии. Исследования проводили на выращиваемых бычках, которые разделили равные три группы. Отбор животных проведен с учетом метода аналогов, где учитывали такие параметры как возраст, живая масса, клинические показатели. В соответствии с программой исследований животные из двух опытных групп потребляли экспериментальные кормовые добавки, а животные из контрольной группы получали исключительно основной рацион. Включение органоминеральных кормовых добавок в рацион бычков позволил повысить показатели живой массы в конце выращивания на $3.3 \%$ и 5.47\%. Эти изменения лучше выражены в скорости роста по периодам вырашивания. Так в опытных группах показатели скорости роста улучшились в 9-12-месячном возрастном периоде вырашивания на 2.42\% и 3.23\%, в 12-15-месячном возрасте на $0.57 \%$ и 0.85\%, а в 15-18-месячном возрасте на $16.01 \%$ и 24.47\%. Таким образом, использование органоминеральных кормовых добавок из природного сырья в кормлении молодняка крупного рогатого скота в условиях Якутии позволило улучшить эффективность их выращивания.

Ключевые слова: скотоводство; кормовые добавки; продуктивность; среднесуточный прирост; живая масса

Для цитирования. Григорьев М.Ф., Григорьева А.И., Сидоров А.А., Попова А.В. Использование органоминеральных кормовых добавок при выращивании молодняка крупного рогатого скота в условиях Якутии // Siberian Journal of Life Sciences and Agriculture. 2021. T. 13, № 3. C. 89-102. DOI: 10.12731/26586649-2021-13-3-89-102

\section{Introduction}

In order to improve the animal feeding in terms of nutritional, mineral and vitamin components, their rations include various feed additives that contain the necessary deficient nutrients. Therefore, the development of new feed additives with an appropriate level is of particular relevance for the animal husbandry $[1,2,3]$.

When organizing full-fledged feeding of animals and birds, an important task is to balance their rations. As a solution, various feed additives can be used to best effective use of the nutritional components of the rations $[4,5,6,7]$.

Zeolites in cattle feeding have shown their effectiveness, but different recommendations indicate different doses and results. This is explained by the fact that zeolites from different deposits have different chemical composition and, accordingly, crystal structure. Therefore, zeolites have different levels of sorption and ion-exchange properties $[8,9,10]$. 
The use of zeolites in various areas of production has proven the effectiveness and prospects of widespread use in agriculture. As a consequence, this became the basis for further search of other zeolite deposits in different countries and regions of the Russian Federation. In the Republic of Sakha (Yakutia), the first zeolite deposit was discovered in 1978 by employees of the Institute of Geology of the Siberian Branch of the Russian Academy of Sciences.

Since that time, the first studies of the possibility of zeolite from the Khonguruu deposit from the Suntarsky district in the industry of Yakutia. The practical possibilities of introducing zeolite hongurin in the oil and the gas industry, construction, mineral resource extraction, environmental protection, agro-industrial complex and other areas of industry were scientifically substantiated [11].

According to information [12], nitrogen-containing substances in the composition of sapropel occupy up to half by weight, carbohydrates can occupy up to $40 \%$ and bitumen compounds, respectively, can reach up to $10 \%$. The sapropel composition is represented by compounds of calcium, phosphorus, sodium, potassium, magnesium, silicon, iron, aluminum, zinc, copper, manganese, cobalt, iodine, molybdenum, nickel, and other substances, as well as vitamins (D, group B), humic acids, hormone-like substances, antibiotics, and other biologically active compounds. The use of a preparation based on sapropel helps to increase the muscle tone animals, while the most effective treatment for endometritis was established with use of the drug in combination with massage and infrared irradiation.

In connection with the above, there is an increasing need for research on the possibility of including feed additives from sapropel and zeolite in animal feeding.

The aim of the research was to study the effect of feed additives from sapropel and zeolite on the indicators of changes in live weight of Simmental young bulls in the conditions of Yakutia.

\section{Materials and methods}

In scientific experiment, the influence of feed additives of sapropel and zeolite hongurin + Kempendyai salt on the growth and development of young Simmental cattle. The experiment grown young cattle was organized in conditions in the Suntarsky region. The experiments were organized on young cattle of the Simmental breed, which were divided into the three groups of 12 animals. The method of analogs was used to select animals. The conditions of detention for all experimental animals were the same, which were kept in the cattle house in the cold season, and in the warm season on pasture. Feeding provided the animals 
with all nutrients at the required rates. According to the experimental conditions, the difference between the control group and the experimental groups was that the animals received feed additives in different doses along with ration. Animals from experimental group II consumed sapropel $0.6 \mathrm{~g} / \mathrm{kg}$ of live weight, zeolite hongurin at the rate of $0.7 \mathrm{~g} / \mathrm{kg}$ of live weight together with $33 \mathrm{~g}$ of Kempendyai salt. In ration of animals of experimental group III was supplemented with: sapropel $0.7 \mathrm{~g} / \mathrm{kg}$ of live weight, zeolite hongurin $0.7 \mathrm{~g} / \mathrm{kg}$ of live weight and $33 \mathrm{~g}$ of Kempendyai salt. Changes in the growth of animals were determined by weighing monthly and determining the average daily gain.

The chemical composition of zeolite hongurin is presented in articles [13, 14]. The chemical composition of sapropel is presented in Table 1.

Table 1.

Sapropel chemical composition

\begin{tabular}{|l|c|}
\hline \multicolumn{1}{|c|}{ Indicators } & Content \\
\hline Water, \% & 92.09 \\
\hline Protein, \% & 0.47 \\
\hline Fat, \% & 0.46 \\
\hline Crude fiber, \% & 0.31 \\
\hline Minerals, \% & 6.48 \\
\hline Calcium, \% & 0.18 \\
\hline Phosphorus, \% & 0.008 \\
\hline
\end{tabular}

Mineral substances are represented by compounds of manganese, zinc, copper, iron, cobalt, molybdenum, iodine, iodine and selenium. Method of mechanical extraction of sapropel is used.

\section{Results and discussion}

Previously, we conducted experiments to determine the optimal rates for the inclusion of sapropels of local lakes in Yakutia in the rations of cattle in Yakutia [15]. The optimal norms of sapropel in feeding cattle at which the best result is achieved and amounted to 0.6 and $0.7 \mathrm{~g} / \mathrm{kg}$ of live weight of the animal.

In order to determine the effectiveness of feed additives, which include sapropel, zeolite hongurin and Kempendyai salt, a scientific experiment was carried out in the Suntarsky district of the Republic of Sakha (Yakutia). The experiment was organized on 3 groups of Simmental cattle bulls at the age of 6-18 months. Each group consists of 12 animals.

The conditions of maintenance for all animals, regardless of the group, were identical, except that the gobies of the experimental groups were fed with or- 
ganomineral feed additives (according to the experiment program). The winter average daily ration of the Simmental bulls at 9 months of age per head per day is presented in Table 2 .

Table 2.

Average daily ration of the Simmental bulls at 9 months of age

\begin{tabular}{|c|c|c|c|c|}
\hline \multirow{2}{*}{ Indicators } & \multirow{2}{*}{ Norm } & \multicolumn{3}{|c|}{ Groups } \\
\hline & & I - control & II - experimental & III - experimental \\
\hline Meadow hay, kg & & 5 & 5 & 5 \\
\hline Compound feed, kg & & 0,5 & 0,5 & 0,5 \\
\hline Herb haylage, kg & & 3 & 3 & 3 \\
\hline \multicolumn{5}{|c|}{ the ration contains: } \\
\hline Exchange energy, MJ & 38 & 43.05 & 43.05 & 43.05 \\
\hline Dry matter, kg & 5 & 6.07 & 6.08 & 6.09 \\
\hline Digestible protein, $\mathrm{g}$ & 540 & 563.22 & 570.76 & 581.35 \\
\hline Crude fiber, $\mathbf{g}$ & 990 & 1720.5 & 1789.77 & 1795.53 \\
\hline Starch, g & 700 & 724.15 & 728.24 & 730.57 \\
\hline Sugar, $g$ & 485 & 378.23 & 390.01 & 397.55 \\
\hline Crude fat, $\mathrm{g}$ & 190 & 196.16 & 208 & 209.46 \\
\hline Calcium, $\mathrm{g}$ & 36 & 36.6 & 38.57 & 40.05 \\
\hline Phosphorus, g & 22 & 20.72 & 22.65 & 23.92 \\
\hline Sulfur, g & 18 & 20.85 & 21.02 & 22.83 \\
\hline Ferrum, $\mathbf{g}$ & 280 & 283.41 & 290.04 & 317.86 \\
\hline Cuprum, $g$ & 40 & 43.56 & 44.03 & 45 \\
\hline Zincum, $\mathrm{g}$ & 210 & 194.25 & 212.82 & 225.05 \\
\hline Cobaltum, $\mathrm{g}$ & 2.8 & 1.65 & 1.96 & 2.5 \\
\hline Manganum, $\mathrm{g}$ & 190 & 224.25 & 232.41 & 249.9 \\
\hline Iodum, g & 1.7 & 1.58 & 1.7 & 1.78 \\
\hline Carotene, mg & 125 & 127.1 & 135.5 & 135.8 \\
\hline Vitamin D, thousand IU & 3 & 2.38 & 2.95 & 3.06 \\
\hline Vitamin E, mg & 165 & 183.01 & 187.95 & 186.2 \\
\hline Vitamin $B_{1}, \mathbf{m g}$ & - & 13.66 & 13.31 & 13.12 \\
\hline Vitamin $\mathrm{B}_{2}, \mathrm{mg}$ & - & 36.27 & 36.05 & 36.73 \\
\hline Vitamin $\mathrm{B}_{3}, \mathbf{m g}$ & - & 64.61 & 64.88 & 64.22 \\
\hline Vitamin $B_{4}, g$ & - & 4.29 & 4.33 & 4.3 \\
\hline Vitamin $B_{5}, \mathrm{mg}$ & - & 102.96 & 103.99 & 102.77 \\
\hline
\end{tabular}

Analysis of animal feeding indicates a lack of mineral nutrition and sugars according to feeding norms [16]. Marked for phosphorus, zinc, cobalt, iodine 
and vitamin D. The inclusion of feed additives in the composition of the rations of the experimental groups made it possible to improve the indices of the content of mineral substances, but also could not eliminate the deficiency in the indicated nutritional elements. The average daily animal ration in the summer is presented in Table 3 .

Table 3 .

Average daily ration of the Simmental bulls at 15-16 months of age

\begin{tabular}{|c|c|c|c|c|}
\hline \multirow{2}{*}{ Indicators } & \multirow{2}{*}{ Norm } & \multicolumn{3}{|c|}{ Groups } \\
\hline & & I - control & II - experimental & III - experimental \\
\hline Pasture grass, $\mathrm{kg}$ & & 20 & 20 & 20 \\
\hline Compound feed, kg & & 2 & 2 & 2 \\
\hline \multicolumn{5}{|c|}{ Ration contains: } \\
\hline $\begin{array}{l}\text { Exchange energy, } \\
\text { MJ }\end{array}$ & 57 & 65.2 & 65.2 & 65.2 \\
\hline Dry matter, kg & 8.2 & 8.41 & 8.41 & 8.41 \\
\hline Digestible protein, $\mathrm{g}$ & 605 & 657.76 & 622.85 & 635.34 \\
\hline Crude fiber, $g$ & 1560 & 2128.95 & 2189.23 & 2210.12 \\
\hline Starch, g & 910 & 932.58 & 940.1 & 948.67 \\
\hline Sugar, $\mathrm{g}$ & 605 & 616.2 & 624.34 & 636.4 \\
\hline Crude fat, $g$ & 270 & 276.53 & 287.46 & 293.51 \\
\hline Calcium, $\mathrm{g}$ & 45 & 61.24 & 63.05 & 64.1 \\
\hline Phosphorus, g & 24 & 26.38 & 27.47 & 28.35 \\
\hline Sulfur, $\mathbf{g}$ & 25 & 24.6 & 25.86 & 26.65 \\
\hline Ferrum, $\mathbf{g}$ & 490 & 512.43 & 587.22 & 610.48 \\
\hline Cuprum, g & 70 & 71.34 & 72.77 & 73.6 \\
\hline Zincum, g & 370 & 376.2 & 387.63 & 395.92 \\
\hline Cobaltum, $\mathrm{g}$ & 4.9 & 2.75 & 3.78 & 4.25 \\
\hline Manganum, $\mathrm{g}$ & 330 & 347.51 & 367.14 & 375.4 \\
\hline Iodum, g & 2.5 & 2.23 & 2.5 & 2.54 \\
\hline Carotene, mg & 180 & 330.45 & 334.23 & 337 \\
\hline $\begin{array}{l}\text { Vitamin D, } \\
\text { thousand IU }\end{array}$ & 3.9 & 3.9 & 3.9 & 3.9 \\
\hline Vitamin E, mg & 260 & 261.56 & 262.24 & 262.49 \\
\hline Vitamin $B_{1}, \mathbf{m g}$ & - & 16.12 & 16.13 & 16.14 \\
\hline Vitamin $B_{2}, \mathbf{m g}$ & - & 49.91 & 49.97 & 49.99 \\
\hline Vitamin $\mathrm{B}_{3}, \mathrm{mg}$ & - & 70.29 & 70.57 & 70.87 \\
\hline Vitamin $B_{4}, g$ & - & 6.62 & 6.78 & 6.92 \\
\hline Vitamin $B_{5}, \mathbf{m g}$ & - & 252 & 257 & 259 \\
\hline
\end{tabular}


Based on the above, we can conclude that in the summer, the content of the main nutrient and mineral elements in the rations of the experimental animals was normal. Feed consumption for the period of the experiment is presented in Table 4 .

Table 4

Feed consumption, energy and protein supply of the Simmental cattle breed ration

\begin{tabular}{|l|c|c|c|c|c|}
\hline \multirow{2}{*}{ Indicators } & \multirow{2}{*}{$\begin{array}{c}\text { Average } \\
\text { per day, kg }\end{array}$} & \multirow{2}{*}{$\begin{array}{c}\text { Duration, } \\
\text { days }\end{array}$} & \multirow{2}{*}{ Total, } & \multicolumn{2}{c|}{ Content } \\
\cline { 5 - 7 } & - & - & - & 17155 & exchange \\
energy, MJ & $\begin{array}{c}\text { digestible } \\
\text { protein, kg }\end{array}$ \\
\hline Norm & 6 & 245 & 1470 & 8673 & 79.38 \\
\hline Meadow hay & 3 & 120 & 360 & 1044 & 11.16 \\
\hline Herb haylage & 20 & 120 & 2400 & 5496 & 48 \\
\hline Pasture grass & 1.8 & 365 & 657 & 6372.9 & 52.56 \\
\hline Compound feed & - & - & - & 21585.9 & 191.1 \\
\hline Total & - & - & - & - & 88.53 \\
\hline $\begin{array}{l}\text { Protein in the ration, } \\
\text { g/EFU }\end{array}$ & - & - & - & 125.83 & - \\
\hline $\begin{array}{l}\text { Complies } \\
\text { with the norm, \% }\end{array}$ & - & - & & &
\end{tabular}

Thus, an analysis of the feeding of the animals showed that the rations contain sufficient nutrients and metabolizable energy. For some trace elements in the ration cattle, there is a deficiency in their content, which is typical for a biogeochemical province.

The inclusion of experimental feed additives in the daily ration of cattle had a positive effect on metabolism, which was reflected in the live weight of the experimental groups (Table 5).

Dynamics of live weight cattle, $\mathrm{kg}(\mathrm{M} \pm \mathrm{m}, \mathrm{n}=12)$

\begin{tabular}{|c|c|c|c|}
\hline \multirow{2}{*}{ Age, months } & \multicolumn{3}{|c|}{ Groups } \\
\cline { 2 - 4 } & I - control & II - experimental & III - experimental \\
\hline $\mathbf{6}$ & $149 \pm 0.89$ & $148 \pm 0.88$ & $147.3 \pm 0.99$ \\
\hline $\mathbf{9}$ & $206 \pm 1.22$ & $207.9 \pm 0.97$ & $210.8 \pm 1.36^{*}$ \\
\hline $\mathbf{1 2}$ & $268 \pm 1.48$ & $271.4 \pm 1.13$ & $274.8 \pm 1.15^{*}$ \\
\hline $\mathbf{1 5}$ & $326.8 \pm 1.49$ & $330.5 \pm 1.43$ & $334.1 \pm 1.53^{* *}$ \\
\hline $\mathbf{1 8}$ & $381.9 \pm 1.71$ & $394.5 \pm 1.52^{* * * *}$ & $402.8 \pm 1.34^{* * *}$ \\
\hline Live weight gain & $232.9 \pm 2.13$ & $246.5 \pm 1.84^{* * *}$ & $255.4 \pm 1.84^{* * *}$ \\
\hline
\end{tabular}

Note: $* \mathrm{P}>0.95 ; * * \mathrm{P}>0.99 ; * * * \mathrm{P}>0.999$ 
At the beginning of the experiment, the average live weight in animals was $147.3-149.0 \mathrm{~kg}$. The changes caused by the influence of feed additives influenced the live weight of the cattle in the experimental groups starting from the age of 9 months. At this age, the cattle of the control group conceded the animals in the experimental groups by $0.92 \%$ and $2.33 \%(\mathrm{P}>0.95)$. At 12 months of age, the animals in control group were lighter than cattle in experimental groups by $1.27 \%$ and $2.24 \%(\mathrm{P}>0.95)$. Upon reaching the age of 15 months, the animals of control group were inferior to those of experimental groups by $1.13 \%$ and $2.23 \%$ ( $\mathrm{P}>0.99)$. At the end of the experiment, upon reaching 18 months of age, the cattle of the control group were inferior in terms of live weight to animals of experimental groups 2 and 3 by $3.30 \%$ and $5.47 \%(\mathrm{P}>0.999)$.

These changes are more noticeable when studying the average daily gains of the experimental cattle Simmental breed (Table 6).

Table 6.

Indicators of average daily gains in live weight of cattle, $g(M \pm m, n=12)$

\begin{tabular}{|c|c|c|c|}
\hline \multirow{2}{*}{ Age, months } & \multicolumn{3}{|c|}{ Groups } \\
\cline { 2 - 4 } & I - control & II - experimental & III - experimental \\
\hline 6-9 months & $633.33 \pm 16.18$ & $665.74 \pm 15.26$ & $705.56 \pm 22.62 *$ \\
\hline 9-12 months & $688.89 \pm 19.05$ & $705.56 \pm 16.67$ & $711.11 \pm 19.05$ \\
\hline 12-15 months & $652.78 \pm 18.41$ & $656.48 \pm 14.5$ & $658.33 \pm 11.37$ \\
\hline 15-18 months & $612.96 \pm 23.96$ & $711.11 \pm 21.71 * *$ & $762.96 \pm 20.12 * * *$ \\
\hline For the period & $646.99 \pm 5.91$ & $684.72 \pm 5.11 * * *$ & $709.49 \pm 5.12^{* * *}$ \\
\hline
\end{tabular}

Note: $* \mathrm{P}>0.95 ; * * \mathrm{P}>0.99 ; * * * \mathrm{P}>0.999$

Experimental research indicates the effectiveness of the inclusion of organomineral feed additives from local raw materials in the feeding of young cattle. During the rearing cattle period of 6-9 months of age, the animal of control group recorded an average of $633.33 \mathrm{~g}$ of daily gain, while in experimental groups II and III this figure was 665.74 and $705.56 \mathrm{~g}$ per day. But at the same time, cattle from the control group were inferior to animals from experimental groups in the 9-12-month age period by $2.42 \%$ and $3.23 \%$.

The superiority of animals from experimental groups over cattle in the control group is traced at 12-15 months of age and amounted to $0.57 \%$ and $0.85 \%$, and at the end of the period at $15-18$ months of age by $16.01 \%(\mathrm{P}>0.99)$ and $24.47 \%$ $(\mathrm{P}>0.999)$. The period of keeping animal in control group, $646.99 \mathrm{~g}$ of gain per day was obtained, while in II and III experimental groups the growth rates were 684.72 and $709.49 \mathrm{~g}$ or comparatively more by $5.83 \%$ and $9.66 \%$, respectively $(\mathrm{P}>0.999)$. 
In order detail the effect of experimental feed additives from local raw materials on the physiological parameters of the Simmental cattle, the biochemical composition of the blood was studied (Table 7).

Table 7.

Animal blood biochemical composition, $(\mathrm{M} \pm \mathrm{m})$

\begin{tabular}{|c|c|c|c|c|c|c|c|}
\hline \multirow{2}{*}{ Groups } & \multirow{2}{*}{$\begin{array}{c}\text { Total } \\
\text { protein, } \\
\text { g/\% }\end{array}$} & \multirow{2}{*}{\begin{tabular}{|c|} 
Reserve \\
alkalinity, \\
$\% \mathrm{CO}_{2}$ \\
\end{tabular}} & \multirow{2}{*}{$\begin{array}{c}\text { Albumin, } \\
\%\end{array}$} & \multicolumn{3}{|c|}{ Globulin, \% } & \multirow{2}{*}{$\begin{array}{c}\text { Protein } \\
\text { ratio }\end{array}$} \\
\hline & & & & alpha & beta & gamma & \\
\hline \multicolumn{8}{|c|}{ at the beginning of the experiment } \\
\hline Norm & $7.2-8.6$ & $46-66$ & $30-50$ & $12-20$ & $10-16$ & $25-40$ & $0.9-1.2$ \\
\hline $\begin{array}{c}\text { I - } \\
\text { control }\end{array}$ & $\begin{array}{c}7.37 \\
\pm 0.32\end{array}$ & $\begin{array}{c}47 \\
\pm 0.53 \\
\end{array}$ & $\begin{array}{l}44.13 \\
\pm 0.94\end{array}$ & $\begin{array}{l}13,73 \\
\pm 0,15 \\
\end{array}$ & $\begin{array}{l}11,57 \\
\pm 0,49 \\
\end{array}$ & $\begin{array}{l}26,50 \\
\pm 0,68\end{array}$ & -0 \\
\hline $\begin{array}{c}\text { II - } \\
\text { experimental }\end{array}$ & $\begin{array}{c}7.3 \\
\pm 0.36 \\
\end{array}$ & $\begin{array}{l}46.17 \\
\pm 1.3 \\
\end{array}$ & $\begin{array}{c}43.83 \\
\pm 1.1 \\
\end{array}$ & $\begin{array}{l}13,67 \\
\pm 0,22 \\
\end{array}$ & $\begin{array}{l}11,50 \\
\pm 0,59 \\
\end{array}$ & $\begin{array}{l}26,77 \\
\pm 0,61 \\
\end{array}$ & $.9 \pm 0.01$ \\
\hline $\begin{array}{c}\text { III - } \\
\text { experimental }\end{array}$ & $\begin{array}{c}7.27 \\
\pm 0.23 \\
\end{array}$ & $\begin{array}{l}46.07 \\
\pm 1.1 \\
\end{array}$ & $\begin{array}{l}43.73 \\
\pm 0.76 \\
\end{array}$ & $\begin{array}{l}13,50 \\
\pm 0,06 \\
\end{array}$ & $\begin{array}{l}11,50 \\
\pm 0,25 \\
\end{array}$ & $\begin{array}{l}26,80 \\
\pm 0,38 \\
\end{array}$ & $0.90 \pm 0.01$ \\
\hline \multicolumn{8}{|c|}{ at the end of the experiment } \\
\hline $\begin{array}{c}\text { I - } \\
\text { control }\end{array}$ & $\begin{array}{c}7.5 \\
\pm 0.25 \\
\end{array}$ & $\begin{array}{c}48 \\
\pm 0.4\end{array}$ & $\begin{array}{c}46.1 \\
\pm 1.07 \\
\end{array}$ & $\begin{array}{l}14,03 \\
\pm 0,41 \\
\end{array}$ & $\begin{array}{l}11,80 \\
\pm 0,85 \\
\end{array}$ & $\begin{array}{l}26,07 \\
\pm 0,72 \\
\end{array}$ & $\begin{array}{c}0.91 \\
\pm 0.04 \\
\end{array}$ \\
\hline $\begin{array}{c}\text { II - } \\
\text { experimental }\end{array}$ & $\begin{array}{c}7.97 \\
\pm 0.39 \\
\end{array}$ & $\begin{array}{l}48.07 \\
\pm 0.35 \\
\end{array}$ & $\begin{array}{c}48.5 \\
\pm 0.47 \\
\end{array}$ & $\begin{array}{l}14,60 \\
\pm 0,90 \\
\end{array}$ & $\begin{array}{r}12,53 \\
\pm 0,49 \\
\end{array}$ & $\begin{array}{l}27,40 \\
\pm 0,62 \\
\end{array}$ & $\begin{array}{c}0.91 \\
\pm 0.03 \\
\end{array}$ \\
\hline $\begin{array}{c}\text { III - } \\
\text { experimental }\end{array}$ & $\begin{array}{l}8.23 \\
\pm 0.2\end{array}$ & $\begin{array}{l}48.83 \\
\pm 0.84\end{array}$ & $\begin{array}{l}50.03 \\
\pm 1.24\end{array}$ & $\begin{array}{l}15,13 \\
\pm 0,12 \\
\end{array}$ & $\begin{array}{l}12,40 \\
\pm 0,59 \\
\end{array}$ & $\begin{array}{l}27,73 \\
\pm 0,23\end{array}$ & $\begin{array}{c}0.92 \\
\pm 0.03\end{array}$ \\
\hline
\end{tabular}

The study of the blood composition of animals showed that the inclusion of feed additives from sapropel, zeolite hongurin and Kempendyai salt did not have a negative effect on physiology of animals. This is confirmed by the fact that the data of blood parameters cattle were within the established norms. We note that there is an increase in the level of total protein and its individual blood fractions in the experimental groups consuming feed additives, which indicates a more intensive metabolism, tissue respiration of the body and better growth of animals.

\section{Conclusion}

The use of organomineral feed additives contributed to the enrichment of the rations of young cattle and contributed to their more intensive growth. At the end of the study, the livestock of the experimental groups were heavier than the control group by $3.3 \%$ and $5.47 \%(\mathrm{P}>0.999)$.

These changes are more noticeable in average daily body weight gains cattle characterizing the growth rate. Young cattle from experimental groups in all 
periods of rearing exceeded the control group: $9-12$ months of age by $2.42 \%$ and $3.23 \%$, at $12-15$ months of age by $0.57 \%$ and $0.85 \%$, at $15-18$ months of age by $16.01 \%(\mathrm{P}>0.99)$ and $24.47 \%(\mathrm{P}>0.999)$.

The analysis of the biochemical composition of blood cattle also did not establish significant changes, all indicators were within the established norms, which indicates the harmlessness of feed additives. Therefore, the use of organomineral feed additives from sapropel and zeolite hongurin \& Kempendyai salt in feeding young cattle in Yakutia.

\section{References}

1. Dawood M.A., Koshio S., Esteban M.A. Beneficial roles of feed additives as immunostimulants in aquaculture: a review. Reviews in Aquaculture, 2018, vol. 10, no. 4, pp. 950-974. http://dx.doi.org/10.1111/raq.12209

2. Kwiatkowska K., Winiarska-Mieczan A., Kwiecień M. Feed additives regulating calcium homeostasis in the bones of poultry-a review. Annals of Animal Science, 2017, vol. 17, no. 2, pp. 303-305. http://dx.doi.org/10.1515/aoas-2016-0031

3. Świątkiewicz S., Arczewska-Włosek A., Szczurek W., Calik J., Krawczyk J., Józefiak D. The influence of selected feed additives on mineral utilisation and bone characteristics in laying hens. Annals of Animal Science, 2018, vol. 18, no. 3, pp. 781. http://dx.doi.org/10.2478/aoas-2018-0017

4. Salem H.B., Smith T. Feeding strategies to increase small ruminant production in dry environments. Small ruminant research, 2008, vol. 77, no. 2-3, pp. 174194. http://dx.doi.org/10.1016/j.smallrumres.2008.03.008

5. Abdelnour S.A., El-Hack M.E.A., Swelum A.A., Perillo A., Losacco C. The vital roles of boron in animal health and production: A comprehensive review. Journal of Trace Elements in Medicine and Biology, 2018, vol. 50, pp. 296-304. https://doi.org/10.1016/j.jtemb.2018.07.018

6. Pino F., Urrutia N.L., Gelsinger S.L., Gehman A.M., Heinrichs A.J. Long-term effect of organic trace minerals on growth, reproductive performance, and first lactation in dairy heifers. The Professional Animal Scientist, 2018, vol. 34, no. 1, pp. 51-58. http://dx.doi.org/10.15232/pas.2017-01680

7. Vila-Donat P., Marín S., Sanchis V., Ramos A.J. A review of the mycotoxin adsorbing agents, with an emphasis on their multi-binding capacity, for animal feed decontamination. Food and Chemical Toxicology, 2018, vol. 114, pp. 246259. https://doi.org/10.1016/j.fct.2018.02.044

8. Marin M.P., Pogurschi E.N., Marin I., Nicolae C.G. Influence of Natural Zeolites Supplemented with Inorganic Selenium on the Productive Performance of Dairy Cows. Pakistan journal of zoology, 2020, vol. 52, no. 2, pp. 775-779. http://dx.doi.org/10.17582/journal.pjz/20190829190816 
9. Khachlouf K., Hamed H., Gdoura R., Gargouri A. Effects of zeolite supplementation on dairy cow production and ruminal parameters-a review. Annals of Animal Science, 2018, vol. 18, no. 4, pp. 857-877. http://dx.doi.org/10.2478/ aoas-2018-0025

10. Dragotoiu D., Marin M., Pogurschi E., Dragotoiu T. The efficiency of using zeolites in dairy farms. International Multidisciplinary Scientific GeoConference: SGEM, 2017, vol. 17, pp. 1129-1136. https://doi.org/10.5593/sgem2017/61/S25.147

11. Kolodeznikov K.E. Poleznye iskopaemye Suntarskogo rayona i perspektivy ikh promyshlennogo osvoeniya [Mineral resources of the Suntarsky district and the prospects for their industrial development]. Yakutsk, 2004. 143 p.

12. Beloborodenko T., Beloborodenko M., Beloborodenko A. Sapropel' i ekologicheski bezopasnye tekhnologii v profilaktike besplodiya korov [Sapropel and ecologically safe technologies in the prevention of cows's infertility]. Veterinariya sel'skokhozyaystvennykh zhivotnykh, 2018, no. 7, pp. 46-52. https://vestnik-hss. kemsu.ru/ru/storage/view/18947

13. Grigorev M.F., Sidorov A.A., Grigoreva A.I. and Sysolyatina V.V. Studying the metabolism of horses when feeding them zeolite-sapropel feed additives in the conditions of Yakutia. IOP Conference Series: Earth and Environmental Science, Vol. 548, 2020, 042008. https://doi.org/10.1088/1755-1315/548/4/042008

14. Chernogradskaya N.M., Grigorev M.F., Grigoreva A.I. and Stepanova S.I. The effect of non-traditional feed additives on the metabolism of young pigs in Yakutia. IOP Conference Series: Earth and Environmental Science, vol. 548, 2020, 022010. https://doi.org/10.1088/1755-1315/548/2/022010

15. Chernogradskaya N.M., Grigorev M.F., Grigoreva A.I., Tatarinova Z.G. Digestibility and Metabolism of Young Cattle in Yakutia after Inclusion of Non-Conventional Feed Additives in their Diet. Proceedings of IV International Scientific and Practical Conference "Modern S\&T Equipments and Problems in Agriculture”. Kemerovo (Russia), June 25, 2020. 2020. pp. 64-73. https://doi. org/10.32743/kuz.mepa.2020.64-73

16. Kalashnikov A.P., Fisinin V.I., Shcheglov V.V., Kleimenov N.I. Normy i ratsiony kormleniya sel'skokhozyaystvennykh zhivotnykh. Spravochnoe posobie [Rates and rations for feeding farm animals]. Moscow: Russian Agricultural Academy, 2003. $456 \mathrm{p}$.

\section{Список литературы}

1. Dawood M.A., Koshio S., Esteban M.A. Beneficial roles of feed additives as immunostimulants in aquaculture: a review // Reviews in Aquaculture, 2018, vol. 10, no. 4, pp. 950-974. http://dx.doi.org/10.1111/raq.12209 
2. Kwiatkowska K., Winiarska-Mieczan A., Kwiecień M. Feed additives regulating calcium homeostasis in the bones of poultry-a review // Annals of Animal Science, 2017, vol. 17, no. 2, pp. 303-305. http://dx.doi.org/10.1515/aoas-2016-0031

3. Świątkiewicz S., Arczewska-Włosek A., Szczurek W., Calik J., Krawczyk J., Józefiak D. The influence of selected feed additives on mineral utilisation and bone characteristics in laying hens // Annals of Animal Science, 2018, vol. 18, no. 3, pp. 781. http://dx.doi.org/10.2478/aoas-2018-0017

4. Salem H.B., Smith T. Feeding strategies to increase small ruminant production in dry environments // Small ruminant research, 2008, vol. 77, no. 2-3, pp. 174194. http://dx.doi.org/10.1016/j.smallrumres.2008.03.008

5. Abdelnour S.A., El-Hack M.E.A., Swelum A.A., Perillo A., Losacco C. The vital roles of boron in animal health and production: A comprehensive review // Journal of Trace Elements in Medicine and Biology, 2018, vol. 50, pp. 296304. https://doi.org/10.1016/j.jtemb.2018.07.018

6. Pino F., Urrutia N.L., Gelsinger S.L., Gehman A.M., Heinrichs A.J. Long-term effect of organic trace minerals on growth, reproductive performance, and first lactation in dairy heifers // The Professional Animal Scientist, 2018, vol. 34, no. 1, pp. 51-58. http://dx.doi.org/10.15232/pas.2017-01680

7. Vila-Donat P., Marín S., Sanchis V., Ramos A.J. A review of the mycotoxin adsorbing agents, with an emphasis on their multi-binding capacity, for animal feed decontamination // Food and Chemical Toxicology, 2018, vol. 114, pp. 246-259. https://doi.org/10.1016/j.fct.2018.02.044

8. Marin M.P., Pogurschi E.N., Marin I., Nicolae C.G. Influence of Natural Zeolites Supplemented with Inorganic Selenium on the Productive Performance of Dairy Cows // Pakistan journal of zoology, 2020, vol. 52, no. 2, pp. 775-779. http://dx.doi.org/10.17582/journal.pjz/20190829190816

9. Khachlouf K., Hamed H., Gdoura R., Gargouri A. Effects of zeolite supplementation on dairy cow production and ruminal parameters-a review // Annals of Animal Science, 2018, vol. 18, no. 4, pp. 857-877. http://dx.doi.org/10.2478/aoas-2018-0025

10. Dragotoiu D., Marin M., Pogurschi E., Dragotoiu T. The efficiency of using zeolites in dairy farms // International Multidisciplinary Scientific GeoConference: SGEM, 2017, vol. 17, pp. 1129-1136. https://doi.org/10.5593/sgem2017/61/S25.147

11. Колодезников К.Е. Полезные ископаемые Сунтарского района и перспективы их промышленного освоения. Якутск, 2004. 143 с.

12. Белобороденко Т. Сапропель и экологически безопасные технологии в профилактике бесплодия коров / Т. Белобороденко, М. Белобороденко, А. Белобороденко // Ветеринария сельскохозяйственных животных. 2018. № 7. C. 46-52. https://vestnik-hss.kemsu.ru/ru/storage/view/18947 
13. Grigorev M.F., Sidorov A.A., Grigoreva A.I. and Sysolyatina V.V. Studying the metabolism of horses when feeding them zeolite-sapropel feed additives in the conditions of Yakutia. IOP Conference Series: Earth and Environmental Science, Vol. 548, 2020, 042008. https://doi.org/10.1088/1755-1315/548/4/042008

14. Chernogradskaya N.M., Grigorev M.F., Grigoreva A.I. and Stepanova S.I. The effect of non-traditional feed additives on the metabolism of young pigs in Yakutia // IOP Conference Series: Earth and Environmental Science, vol. 548, 2020, 022010. https://doi.org/10.1088/1755-1315/548/2/022010

15. Chernogradskaya N.M., Grigorev M.F., Grigoreva A.I., Tatarinova Z.G. Digestibility and Metabolism of Young Cattle in Yakutia after Inclusion of Non-Conventional Feed Additives in their Diet // Proceedings of IV International Scientific and Practical Conference "Modern S\&T Equipments and Problems in Agriculture". Kemerovo (Russia), June 25, 2020. 2020, pp. 64-73. https://doi.org/10.32743/kuz.mepa.2020.64-73

16. Калашников А.П. Нормы и рационы кормления сельскохозяйственных животных. Справочное пособие. 3-е издание переработанное и дополненное / Под ред. А.П. Калашникова, В.И. Фисинина, В.В. Щеглова, Н.И. Клейменова. М.: Россельхозакадемия. 2003. 456 с.

\section{DATA ABOUT THE AUTHORS}

Mikhail F. Grigorev, Associate Professor of the Department of General Zootechnics, Faculty of Agricultural Technology

Arctic State Agrotechnological University

3, Sergelyakhskoe Str., Yakutsk, Republic of Sakha (Yakutia), 677007, Russian Federation

grig_mf@mail.ru

ORCID: 0000-0002-5910-9268

Alexandra I. Grigoreva, Senior lecturer of the Department of Higher Mathematics North-Eastern Federal University named after M.K. Ammosov 48, Kulakovsky Str., Yakutsk, Republic of Sakha (Yakutia), 677013, Russian Federation shadrina_ai@mail.ru ORCID: 0000-0002-5968-2400

Andrey A. Sidorov, Senior Lecturer of Department of Food Technologies and Food Industry, Faculty of Agricultural Technology

Arctic State Agrotechnological University

3, Sergelyakhskoe Str., Yakutsk, Republic of Sakha (Yakutia), 677007, Russian Federation grig_mf@mail.ru 
Akulina V. Popova, Associate Professor of the Department of General Zootechnics, Faculty of Agricultural Technology

Arctic State Agrotechnological University

3, Sergelyakhskoe Str., Yakutsk, Republic of Sakha (Yakutia), 677007, Russian Federation

grig_mf@mail.ru

\section{ДАННЫЕ ОБ АВТОРАХ}

Григорьев Михаил Федосеевич, кандидат сельскохозяйственных наук, доцент кафедры общей зоотехнии

ФГБОУ ВО «Арктический государственный агротехнологический университет»

ш. Сергеляхское 3 км, 3, г. Якутск, Республика Саха (Якутия), 677007, Российская Федерация

grig_mf@mail.ru

Григорьева Александра Ивановна, старший преподаватель кафедры высшей математики

Федеральное государственное автономное образовательное учреждение высшего образования "Северо-Восточный федеральный университет имени М.К. Аммосова»

ул. Кулаковского, 48, г. Якутск, Республика Саха (Якутия), 677013, Российская Федерация

shadrina_ai@mail.ru

Сидоров Андрей Андреевич, старший преподаватель кафедры пищевых технологий и индустрии питания

ФГБОУ ВО «Арктический государственный агротехнологический университет»

ш. Сергеляхское 3 км, 3, г. Якутск, Республика Саха (Якутия), 677007, Российская Федераџия

grig_mf@mail.ru

Попова Акулина Васильевна, кандидат сельскохозяйственных наук, доцент кафедры общей зоотехнии ФГБОУ ВО «Арктический государственный агротехнологический университет»

ш. Сергеляхское 3 км, 3, г. Якутск, Республика Саха (Якутия), 677007, Российская Федерация grig_mf@mail.ru 